\title{
THE ROLE OF DIGITAL COMMUNICATION TOOLS IN THE PROCESS OF HUMANIZATION OF SMART CITY
}

\author{
Barbara ROŻAŁOWSKA \\ Silesian University of Technology; barbara.rozalowska@polsl.pl, ORCID: 0000-0003-3455-1073
}

Purpose: The aim of the article is to characterize the channels of communication between citizens and the authorities of Polish cities and check the extent to which cities use the digital possibilities of contact.

Design/methodology/approach: In order to find out about the communication patterns, 280 randomly selected cities were examined. The subject of communication was part of a broader study on the functioning of a smart city in Poland. The theoretical basis used in the article is human smart city. This concept assumes that the functioning of cities requires social participation and effective communication also using channels supported by information and communication technologies (ICT).

Findings: The conclusions of the study show that most cities still used the traditional approach in dealing with the locals. Personal meetings and a paper-based message are preferred.

Research limitations/implications: In further research, it is worth observing in which direction the development of city websites is progressing, whether there are general tendencies to expand meeting places between residents, groups of residents and city officials, and what new functionalities are offered by city portals, including social networks. Quantitative research should be extended with case studies to better illustrate the subject of communication.

Practical implications: The article can be used by municipal authorities to improve communication with residents. Moreover, it enables comparisons to be made between groups of cities differing in the number of inhabitants.

Originality/value: The text considers the subject of communication between the authorities and residents, which has never been studied on a national research sample. New are also developed theoretical models on which to work.

Keywords: citizen participation, smart city, e-participation, social media, digital engagement.

Category of the paper: Research paper. 


\section{Introduction}

The idea of a smart city is already well established in the discourse on the possibility of using information technology in the development of cities and urban communities around the world. From the moment this topic appeared in the scientific discussion, its gradual evolution from the "technology driven method" to the "human driven method" (Kummitha, 2017), from smart city to smart citizen (Shelton, and Lodato, 2019) or the transformation of management from top-down on the bottom-up (Breuer et al., 2014). Initially, the focus was on the use of internet of things (IoT), urban applications and other data collection and gathering tools, which can be called urban informatics (Foth, 2018). After taking into account that the use of IT is not an end in itself, but should serve the development of the entire urban system, the perception of the city has become citizen-centric (Wolff, 2020). The definition of Caragliu (2011) shows that the human factor is very important: "city can be defined as 'smart' when investments in human and social capital and traditional (transport) and modern (ICT) communication infrastructure fuel sustainable economic development and a high quality of life, with a wise management of natural resources, through participatory governance.

The area of scientific reflection on the smart city also expanded the cultural changes taking place in the city management models. The new participatory way of city governance is now seen as better at implementing urban policies and as capable of achieving more complex goals (Simonovski et al., 2017; Sengboon et al., 2018). Although civic participation is not a new phenomenon, it has long been regarded as a pillar of democracy and the basis of civil society activities aimed at developing civic skills (Michels, and de Graaf, 2010). The new promoted version has been extended with digitization elements, provided in the smart city package, which is why some authors write directly about Digital Citizen Participation (Bouzguenda et al., 2019).

Human smart city means looking at the city from the perspective of its inhabitants and their needs, instead of focusing on the requirements of efficiency and reliability of technical systems (Pfäffli et al., 2018). De Oliveria in his manifesto described the idea as follows: "The human smart cities are those where governments engage citizens be being open to be engaged by citizens, supporting the co-design of technical and social innovation processes through a peerto-peer relationship based on reciprocal trust and collaboration. The human smart city is a city where people - citizens and communities - are the main actors of urban 'smartness'“6 (de Oliveira, 2016, p. 201). A human smart city is therefore a city based on civic participation, efficient in the multidirectional flow of information, involving various stakeholders in order to improve the quality of life. It is clearly visible that the role of communication with residents in the city is beginning to take on a new meaning. The goal is not only to provide information about the residents' own needs, but also to be able to communicate widely and cooperate with each other. In smart city, thanks to the use of social media by city authorities, the way of 
communication between various stakeholders in the city has expanded. Two-way communication has emerged instead of simply providing information in the top-bottom direction (Johnson et al., 2020). The intelligence of an urban area depends on the extent to which digitization will make it easier for the city, district or smaller ecosystems to become more open, participatory and experimental. Proprietary platforms and social media are becoming the main nodes connecting various stakeholders in the city's digital space. Platforms that are hosted and controlled by municipal government are very important. They make it possible to provide information and obtain data sent by stakeholders, e.g. during voting. Berntzen and Johannessen (2016) list many advantages of such a tool. It covers many important areas for various city users, from providing current information, to specialized urban planning tools and geographic information systems. Their social impact is also appreciated, as in places with low civic participation it can contribute to the creation of grassroots movements and improve social inclusion rates. The same is happening in the area of social media, which allow the inclusion of a wider representation of residents in discussions about the city (Zavattaro et al. 2015). In addition, aggregation of data from social media can provide valuable information (Berntzen et al., 2016).

The aim of the article is to consider the channels of communication between the authorities and residents as well as the conditions of civic participation in young Polish cities in terms of the degree of development of democracy. Only after the local government reform in 1990, introducing decentralization of management, cities and their citizens gained self-government (Izdebski, 2014). The development of democracy happened at the same time as the IT revolution that introduced smart solutions to city systems was taking place in other cities around the world. It is therefore interesting what strategies for communicating with residents have been chosen in cities of various sizes and to what extent the Internet has facilitated dialogue for Polish cities with the locals. For this purpose, data obtained in a nationwide survey conducted by the Department of Organization and Management of the Silesian University of Technology were used.

\section{Communication channels in a smart city}

Contact with the residents of smart city is possible thanks to off-line and on-line communication. Bertnzen and Johannessen (2016) claim that the traditional ways of dialogue between the authorities and citizens, including focus groups, surveys and town-hall meetings are still important activities undertaken by city officials. However, the use of communication and information technologies (ICT) allows more people to participate in the decision-making processes. Among the possible participatory activities, smart city offers new means of communication directed by residents towards the city authorities. Thanks to various 
communication channels, such as: e-mail, electronic forms, webGIS, social networks and mobile applications, it is possible to report matters of various importance to city officials. They may even be information about damaged benches, holes in the roads.

An important role in the inclusion of citizens in city affairs plays a way to transfer information. Participation is strengthened when a given means of communication is perceived as easy-to-use tools and when residents receive positive feedback from the local government (Kopackowa, Komarkova, 2020). However, the implementation of new solutions requires time, mutual support and building an atmosphere of trust. The original use of city websites resulted from treating the city as an enterprise, therefore the content posted on them focused on providing information about the city and facilitating transactions concluded by the city and business (Urban, 2002). In such a model, there was no room for dialogue with the residents, unless they were entrepreneurs.

Johnson, Robertson, and Philpot (2020) distinguish between traditional and transactional types of contacts in their research on the means of communication between authorities and stakeholders. They indicate four modes of transaction: intentional contribution (type), intermediated by third party (tweet), convened or requested transaction (tap), and transaction based on movement (pass). Most related to traditional means of communication is type, which includes a form of intentional citizen-initiated contact such as letter, telephone, e-mail. Tweet mode refers to communication using social media platforms managed by third parties not related to the municipal government. A tap is a transaction convened at the request of the authorities and requires online activity, e.g. voting for projects in the civic budget. However, this is done without the intermediation of external companies in relation to the city authorities. A pass is a transaction resulting from collecting data using sensors, tracking traces on the Internet in order to learn about the activity, behaviour and habits of users of a given space. It is often perceived as the most controversial due to the privacy issue and ignorance of the people from whom the data is collected. Technologies typical for a smart city are used here, i.e. sensors and cameras.

Table 1.

Hierarchy for smart city citizen engagement activities

\begin{tabular}{|l|l|l|}
\hline Forms of citizen engagement & Coded type of acitvity \\
\hline Transactive & Online inputs with formal standing in decision process & $\begin{array}{l}\text { Online public consultation platforms } \\
\text { (desktop and mobile) } \\
\text { Social media }\end{array}$ \\
\hline Traditional & $\begin{array}{l}\text { Online inputs without formal standing in decision } \\
\text { process. Public discussion, interviews, surveys, hands- } \\
\text { on activities and targeted sessions with formal standing }\end{array}$ & $\begin{array}{l}\text { Focus groups } \\
\text { Public discussion } \\
\text { Workshops and hands-on activities } \\
\text { Surveys }\end{array}$ \\
\hline & Passive information delivery & $\begin{array}{l}\text { Audio-visual information } \\
\text { Website information }\end{array}$ \\
\hline
\end{tabular}

Source: Johnson, P.A., Acedo, A., and Robinson P.J. (2020) Canadian Smart Cities: Are We Wiring New Citizen-local Government Interactions? The Canadian Geographer/Le Géographe Canadien, p. 6. https://doi.org/10.1111/cag.12623. 
The division of communication channels into transactive and traditional ones, proposed by the researchers, is presented in Table 1. Transactive channels are typical of activities with the highest level of participation of residents. They require the use of ICT in the relationship between city officials and residents. Canadian research on the relationship between citizen participation, management and the type of communication channels used shows that they most often still use traditional methods of involving residents in city activities. Organizing face-toface meetings is still the most popular (Johnson et al., 2020). Research explains the role of particular communication channels.

\section{Methods}

The first method used was based on an analysis of the literature to conceptualize the research. The articles were selected on the basis of scientific text search engines: Science Direct, Google Scholar, Scopus, and Web of Science. The following keywords were searched for: citizen participation, smart city, e-participation, social media and digital engagement. Subsequently, articles whose titles and summaries corresponded to the subject of this work were qualified for research.

Table 2.

Characteristics of communication channels in a smart city

\begin{tabular}{|l|l|}
\hline $\begin{array}{l}\text { Features of } \\
\text { communication channels }\end{array}$ & Examples \\
\hline Initiated by officials & $\begin{array}{l}\text { Information on the city's website, printed materials, surveys of residents, } \\
\text { consultations, meetings with residents. }\end{array}$ \\
\hline Initiated by residents & Civic initiatives; ideas, complaints and comments submitted by residents. \\
\hline Indirect & Transmission in writing or via the website, telephone, social media. \\
\hline Direct & Face-to-face meetings between officials and residents. \\
\hline One-way & Information via website, leaflets, brochures, digital information boards. \\
\hline Two-way & Social media, interactive websites, chats with officials, telephone, letter, e-mail. \\
\hline Supported by ICT & $\begin{array}{l}\text { City websites and mobile applications, e-mail, social media, digital information } \\
\text { board. }\end{array}$ \\
\hline $\begin{array}{l}\text { Traditional - without ICT } \\
\text { support }\end{array}$ & Letter, phone, flyer, brochure, face-to-face meeting. \\
\hline Individual & E-administration; ideas, complaints, comments and individual initiatives. \\
\hline Group & Social media, group civic initiatives. \\
\hline Formal & $\begin{array}{l}\text { Consultations via the Internet, consultations in direct contact with groups of } \\
\text { residents, surveys. }\end{array}$ \\
\hline Informal & Social media. \\
\hline
\end{tabular}

The aim of the next stage of the research was to develop a theoretical research model, which was then used in extensive studies of Polish cities. The research was inspired by the considerations of Canadian researchers on the involvement of citizens in the city's affairs (Johnson, Robinson, and Philpot, 2020; Johnson, Acedo, and Robinson, 2020). 
The model proposed by Canadian researchers was extended to include a juxtaposition of various interweaving features of communication channels. The applied categorizations allow for the specification of the characteristics of various forms of activities undertaken by the authorities and citizens. They are organized as follows: officials initiated - initiated by residents, indirect - direct, one-way - two-way, ICT-supported - traditional without ICT support, individual - group, with formal standing in decision process - without formal standing in decision process. Examples are presented in Table 2.

The research assumed that a smart city is a city where communication between officials and residents takes place not only through digital platforms and mobile applications. Technology is more of an intermediary, while the main goal is to activate and enable residents to decide on matters related to the functioning of the city, which can be helped by a variety of communication channels. Therefore, the balance between pairs of channel characteristics is viewed as an asset.

An extensive questionnaire was addressed to 280 randomly selected city offices in Poland, which accounts for almost $30 \%$ of all cities. Research problems related to the methods of communication between city offices and residents constituted one of the 6 modules related to the smart city category. The main questions relevant to the research process are:

whether information technologies have replaced the traditional way of communicating with the inhabitants;

$>$ to what extent large urban centres (if this is true) outpaced the smaller ones in using the Internet in contacts between city authorities and residents;

what are the characteristics of the communication process in a smart city.

Table 3.

Division of communication channels

\begin{tabular}{|c|c|}
\hline Digital communication channels & Traditional communication channels \\
\hline $\begin{array}{l}>\text { city website } \\
\text { a website or subpage devoted to public } \\
\text { consultations } \\
\text { website dedicated to expressing opinions, } \\
\text { suggestions, commenting } \\
>\text { social media } \\
>\text { urban mobile applications } \\
>\text { digital information boards }\end{array}$ & $\begin{array}{l}>\text { traditional letter } \\
>\text { written opinions submitted directly to the city hall } \\
>\text { telephone } \\
>\text { face-to-face contact with the clerk } \\
>\text { sounding }\end{array}$ \\
\hline
\end{tabular}

The research tool was constructed to obtain detailed information on the communication channels used. It was assumed that nowadays all Polish cities have a city website, which, however, may differ in the degree of transactivity. The general division of communication channels includes two categories: digital and traditional (Table 3). Digital communication channels are primarily related to the city's website, which can be a very complex tool that allows you to conduct online consultations, chat with an official or collect ideas and comments from residents. Social media are also important for creating a space for dialogue, as they allow for greater interactivity and encourage participation (Mossberger et al., 2013). 


\section{Results}

Research reveals that Polish cities most often use traditional methods of contacting their residents (Fig. 1). The most popular forms of contact are face-to-face meetings with officials. The research did not distinguish whether these are meetings in the city hall or in another city space, and whether the meeting is related to consultations. Almost the same number of respondents indicated the letter form as an important communication channel. Slightly less, $70.7 \%$ allows the letter to be left at the municipal office. Sending a regular letter may be considered an alternative for people who do not use a computer.

Another traditional method is opinion polls, which as a form of one-way communication are usually used to measure quality of life. However, such research is expensive, which is why the largest cities conduct them more often among their inhabitants. $72 \%$ of the surveyed city offices confirmed that such research is carried out. The overall result for all cities is around $30 \%$.

The second category of communication channels is related to the use of Internet tools. Most cities communicate with residents via e-mail, although few (13.2\%) have a special form for sending content directly from the city's website. Social media are becoming more and more popular places to exchange content between different users of urban space. Facebook is definitely dominant in Polish cities with a result of $73.6 \%$, while Tweeter and Instagram are used by a small percentage of cities. It is a form of communication mediated by large companies external to city councils (Johnson, Robertson, and Philpot, 2020). Analysing the city size, it can be seen that cities with more than 100,000 residents use various sets of possible communication channels and definitely differ from smaller towns. It looks like the number of 100,000 inhabitants, it becomes the limit quantity. Above it, cities are forced to introduce more communication channels in order to improve the quality of contact with residents, as it becomes impossible to use only traditional forms. In the group of the largest cities, the use of social media is increasing - 92\% of them stay in touch via Facebook, and Instagram is increasingly important (40\%). Tweeter in Polish cities did not gain popularity, it was noticed as a supporting medium in cities over 50 thousand residents. In this group, only every fifth city uses Tweeter, while among the larger cities with more than 100 thousand residents it is every third city. 


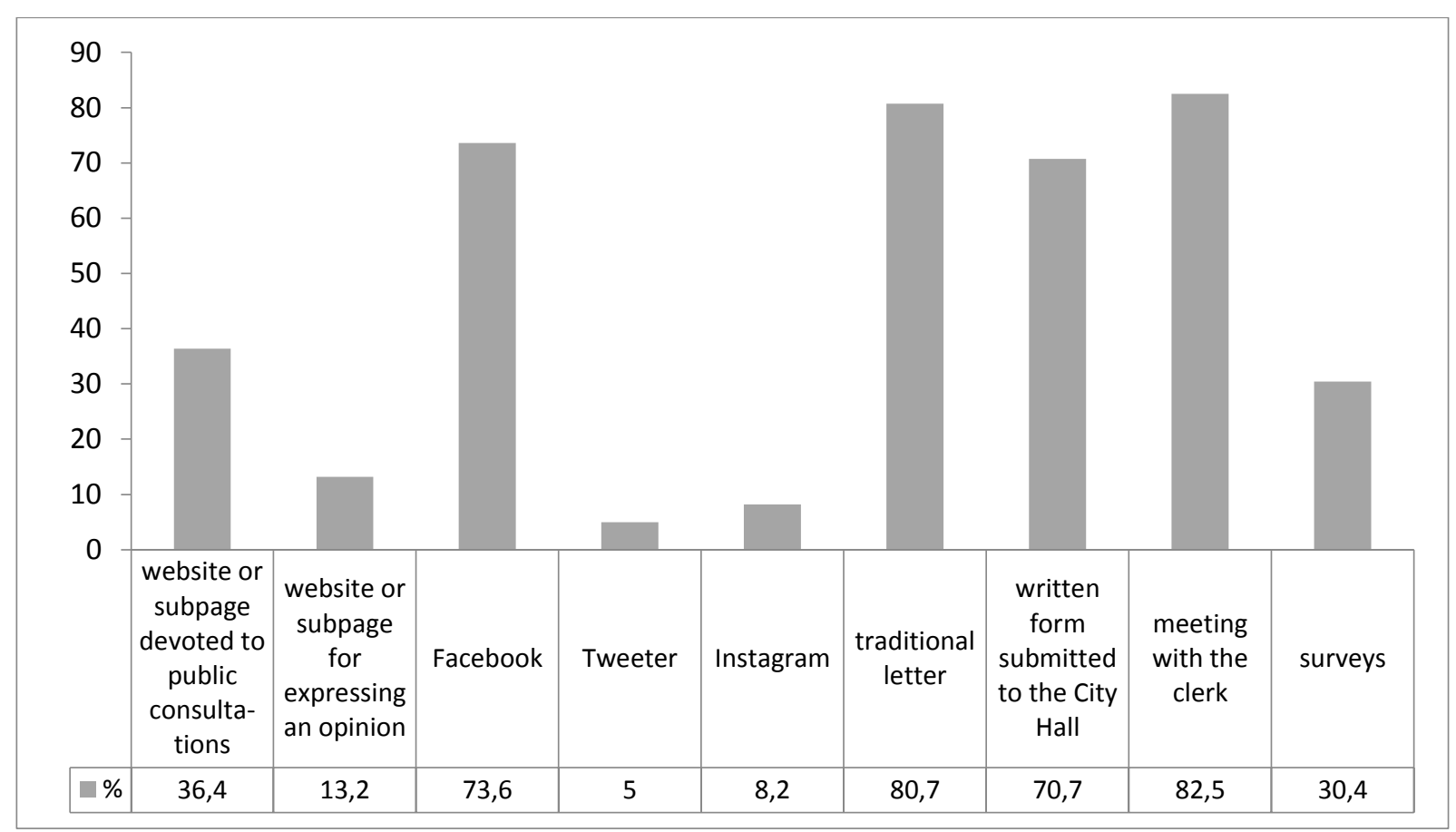

Figure 1. Communication channels used in Polish cities.

Table 3.

Communication channels depending on the city size (\% of yes answers)

\begin{tabular}{|c|c|c|c|c|c|c|}
\hline \multirow[b]{2}{*}{$\begin{array}{l}\text { What channels do the city authorities use } \\
\text { to communicate with residents? }\end{array}$} & \multicolumn{6}{|c|}{ Number of inhabitants (in thousands) } \\
\hline & $\begin{array}{l}\text { Up to } \\
5000\end{array}$ & $\begin{array}{l}5001- \\
10000\end{array}$ & $\begin{array}{l}10001- \\
25000\end{array}$ & $\begin{array}{l}25001- \\
50000\end{array}$ & $\begin{array}{l}50001- \\
100000\end{array}$ & $\begin{array}{l}\text { More } \\
\text { than } \\
\mathbf{1 0 0 0 0 0}\end{array}$ \\
\hline $\begin{array}{l}\text { a website or subpage devoted to public } \\
\text { consultations }\end{array}$ & 23.1 & 23.3 & 30.9 & 55.3 & 33.3 & 84.0 \\
\hline $\begin{array}{l}\text { a website or subpage dedicated to expressing } \\
\text { opinions and suggestions, commenting on } \\
\text { current issues important to residents }\end{array}$ & 5.1 & 13.3 & 14.9 & 15.8 & 8.3 & 20.0 \\
\hline social media - Facebook & 53.8 & 60.0 & 75.5 & 92.1 & 83.3 & 92.0 \\
\hline social media - Twitter & 0.0 & 1.7 & 0.0 & 0.0 & 20.8 & 32.0 \\
\hline social media - Instagram & 5.1 & 6.7 & 4.3 & 5.3 & 4.2 & 40.0 \\
\hline $\begin{array}{l}\text { opinions and comments may be sent by } \\
\text { traditional mail }\end{array}$ & 79.5 & 75.5 & 77.7 & 89.5 & 79.2 & 96.0 \\
\hline $\begin{array}{l}\text { opinions and comments in writing can be left } \\
\text { at the city hall or at a selected point in the } \\
\text { city }\end{array}$ & 69.2 & 60.0 & 63.8 & 86.8 & 83.3 & 88.0 \\
\hline $\begin{array}{l}\text { opinions and comments may be presented to } \\
\text { the official in person }\end{array}$ & 82.1 & 78.3 & 85.1 & 86.8 & 70.8 & 88.0 \\
\hline surveys & 17.9 & 16.7 & 25.5 & 52.6 & 25.0 & 72.0 \\
\hline
\end{tabular}

It can be noticed that in smaller cities, traditional communication channels not supported by ICT are much more often chosen. Only few cities have their own smartphone applications for contacting residents. Among the largest Polish cities, only Warsaw has such an application. 


\section{Discusion}

The study reveals that in a smart city, two-way communication supported by the Internet does not dominate among the possible ways of transmitting information. In Poland, only $36.4 \%$ of cities have a website dedicated to public consultations, which enables dialogue with city authorities. Traditional methods of contacting residents are more often chosen. Canadian researchers (Johnson, Acedo, and Robinson, 2020) drew similar conclusions from their research. The problem of working out the ways in which the Internet is used to engage residents remains valid. As noted by Feerney and Brown (2017), city websites can greatly influence the development of democracy by providing places for civic dialogue and transparency of information, but most of them do not implement new solutions to improve the communication process. The development of communication channels is related to the overall vision of who a city user is. Researchers indicate that the dominant position of a city dweller can be described as service user or entrepreneurial. It is rare to see a citizen in an inhabitant whose actions are not related to politics or market activity (Cardullo, and Kitchen, 2019). This is why the city's websites still lack space for two-way exchange of information between citizens and city authorities. Urban (2002) had shown in his research the relationship between the democratic use of websites and the degree of city development much earlier. Richer city more often used city websites to support the lives of their inhabitants, while the poorer ones treated their websites as a shop window for attracting business and tourists to the city. In Poland nowadays, these largest cities have the best conditions to develop towards a smart city (Jonek-Kowalska, 2019).

The inclusion of social media in the communication channels used gave the residents hope for the development of dialogue between the authorities and the residents. About $73 \%$ of offices in Polish cities use social media, which is a low percentage compared to other countries. In the USA, already in 2013, 92.4\% of cities used Facebook (Norris, and Reddick, 2013). The role of social media is appreciated despite the informal formula of contacts between users. This is evidenced by the inclusion of more and more alternative portals, such as Instagram, YouTube by other cities.

Large Polish cities - as research has shown - use much more communication channels, both traditional and digitized, which enable the participation of diverse groups of residents. The slow process of "the evolution from people as residents, consumers, participants, to cocreators" may be an obstacle in the democratization of space (Foth, 2018). The activity of residents is still relatively low (Inglot-Brzęk, 2017) and attachment to traditional methods of transmitting information between the city hall and residents is visible. The problems faced by cities planning to involve citizens in the discussion about the city do not only concern how to encourage residents to be active. Researchers indicate that obtaining a real representation of all smart city users is extremely difficult. This is mainly due to the fact that the initiatives are 
targeted at people with an information technology (IT) education and address the issue of "entrepreneurial citizenship" (Engelbert et al., 2019). The development of social capital could contribute to the improvement of participation rates in civic life in cities aspiring to be "smart" (Kuzior, and Sobotka, 2019).

In further research, it is worth observing in which direction the development of city websites is progressing, whether there are general tendencies to expand meeting places between residents, groups of residents and city officials, and what new functionalities are offered by city portals, including social networks. It is also puzzling whether digitized communication channels are able to dominate the contacts between the authorities and residents in a smart city.

\section{Conclusions}

Information technologies have not replaced traditional methods of information exchange between city authorities and users of urban space, as direct activities are still dominant among them. However, in the largest cities, more frequent use of new communication channels supported by ICT can be observed. This increases the possibilities of participation and co-governance of the city, which should result in an increase in the quality of life. Regardless of whether the inhabitants take full advantage of the new possibilities of transmitting information, cities, especially the larger ones, are becoming more and more open to citizens and gain the ability to quickly respond to changes in the changing reality.

\section{Acknowledgements}

The study used data obtained in studies conducted at the beginning of 2020 by the Department of Organization and Management of the Silesian University of Technology. They were financed from the part of the research subsidy of the department 13/990/BK_19/0138. The subject of civic participation and communication channels used in Polish cities is a part of a broader research on the functioning of smart city in Poland. 


\section{References}

1. Bertzen, L., Johannessen, M.R. (2016). The Role of Citizen Participation in Municipal Smart City Projects: Lessons Learned from Norway. In: J.R. Gil-Garcia, T.A. Pardo, T. Nam, Smarter as the new urban agenda a comprehensive view of the 21 st century city. Springer International Publishing.

2. Bouzguenda, I., Alalouch, C., \& Fava, N. (2019). Towards smart sustainable cities: A review of the role digital citizen participation could play in advancing social sustainability. Sustainable Cities and Society, 50, 101627. https://doi.org/10.1016/ j.scs.2019.101627.

3. Breuer, J., Walravens, N., \& Ballon, P. (2014). Beyond defining the smart city. Meeting top-down and bottom-up approaches in the middle. TeMA - Journal of Land Use, Mobility and Environment. https://doi.org/10.6092/1970-9870/2475.

4. Caragliu, A., Del Bo, C., \& Nijkamp, P. (2011). Smart cities in Europe. Journal of Urban Technology, 18(2), pp. 65-82. https://doi.org/10.1080/10630732.2011.601117.

5. Cardullo, P., \& Kitchin, R. (2019). Smart urbanism and smart citizenship: The neoliberal logic of 'citizen-focused' smart cities in Europe. Environment and Planning C: Politics and Space, 37(5), pp. 813-830. https://doi.org/10.1177/0263774X18806508.

6. de Oliveira, À.D. (2016). The human smart cities manifesto: A global perspective. In: W.G. Concilio \& F. Rizzo (eds.), Human Smart Cities (pp. 197-202). Springer International Publishing. https://doi.org/10.1007/978-3-319-33024-2_11.

7. Engelbert, J., van Zoonen, L., \& Hirzalla, F. (2019). Excluding citizens from the European smart city: The discourse practices of pursuing and granting smartness. Technological Forecasting and Social Change, 142, pp. 347-353. https://doi.org/10.1016/ j.techfore.2018.08.020.

8. Feeney, M.K., \& Brown, A. (2017). Are small cities online? Content, ranking, and variation of U.S. municipal websites. Government Information Quarterly, 34(1), pp. 62-74. https://doi.org/10.1016/j.giq.2016.10.005.

9. Foth, M. (2018). Participatory urban informatics: Towards citizen-ability. Smart and Sustainable Built Environment, 7(1), pp. 4-19. https://doi.org/10.1108/SASBE-10-20170051.

10. Inglot-Brzęk, E. (2017). Znaczenie roli władz samorządowych w kształtowaniu partycypacji obywatelskiej. Nierówności społeczne a wzrost gospodarczy, 50(2), pp. 329-348. https://doi.org/10.15584/nsawg.2017.2.21.

11. Izdebski, H. (2014). Samorząd terytorialny. Podstawy ustroju i działalności. Warszawa: PWN. 
12. Johnson, P.A., Acedo, A., \& Robinson, P.J. (2020). Canadian smart cities: Are we wiring new citizen-local government interactions? The Canadian Geographer/Le Géographe Canadien, cag. 12623. https://doi.org/10.1111/cag.12623.

13. Johnson, P.A., Robinson, P.J., \& Philpot, S. (2020). Type, tweet, tap, and pass: How smart city technology is creating a transactional citizen. Government Information Quarterly, 37(1), 101414. https://doi.org/10.1016/j.giq.2019.101414.

14. Jonek- Kowalska, I. (2019). Identification of budgetary sources of risk in polish smart cities practical approach. Scientific Papers of Silesian University of Technology. Organization and Management Series, 9(6), pp. 147-162. https://doi.org/10.29119/16413466.2019.140.12.

15. Kopackova, H., \& Komarkova, J. (2020). Participatory technologies in smart cities: What citizens want and how to ask them. Telematics and Informatics, 47, 101325. https://doi.org/10.1016/j.tele.2019.101325.

16. Kummitha, R.K.R., \& Crutzen, N. (2017). How do we understand smart cities? An evolutionary perspective. Cities, 67, pp. 43-52. https://doi.org/10.1016/ j.cities.2017.04.010.

17. Kuzior, A., Sobotka, B., \& Syntea, S.A. (2019). The role of social capital in the development of smart cities. Scientific Papers of Silesian University of Technology. Organization and Management Series, 134, pp. 109-119. https://doi.org/10.29119/16413466.2019.134.9.

18. Lim, S., Abdul Malek, J., Hussain, M.Y., \& Tahir, Z. (2018). Citizen participation in building citizen-centric smart cities. Malaysian Journal of Society and Space, 14(4), pp. 42-53. https://doi.org/10.17576/geo-2018-1404-04.

19. Michels, A., \& De Graaf, L. (2010). Examining citizen participation: Local participatory policy making and democracy. Local Government Studies, 36(4), pp. 477-491. https://doi.org/10.1080/03003930.2010.494101.

20. Mossberger, K., Wu, Y., \& Crawford, J. (2013). Connecting citizens and local governments? Social media and interactivity in major U.S. cities. Government Information Quarterly, 30(4), pp. 351-358. https://doi.org/10.1016/j.giq.2013.05.016.

21. Norris, D.F., \& Reddick, C.G. (2013). Local e-government in the united states: Transformation or incremental change? Public Administration Review, 73(1), 165-175. https://doi.org/10.1111/j.1540-6210.2012.02647.x.

22. Pfäffli, M., Habenstein, A., Portmann, E., \& Metzger, S. (2018). Eine architektur zur transformation von städten in human smart cities. HMD Praxis der Wirtschaftsinformatik, 55(5), pp. 1006-1021. https://doi.org/10.1365/s40702-018-00451-z.

23. Shelton, T., \& Lodato, T. (2019). Actually existing smart citizens: Expertise and (Non)participation in the making of the smart city. City, 23(1), pp. 35-52. https://doi.org/10.1080/13604813.2019.1575115. 
24. Urban, F. (2002). Small town, big website? Cities, 19(1), pp. 49-59. https://doi.org/10.1016/S0264-2751(01)00045-2.

25. Wolff, A., Barker, M., Hudson, L., \& Seffah, A. (2020). Supporting smart citizens: Design templates for co-designing data-intensive technologies. Cities, 101, 102695. https://doi.org/10.1016/j.cities.2020.102695.

26. Zavattaro, S.M., French, P.E., \& Mohanty, S.D. (2015). A sentiment analysis of U.S. local government tweets: The connection between tone and citizen involvement. Government Information Quarterly, 32(3), pp. 333-341. https://doi.org/10.1016/j.giq.2015.03.003. 